\title{
Strategic Management for SMEs: For the Projection to Global Markets
}

\author{
Wilson Cradazco ${ }^{1}$, William Niebles ${ }^{1}$, Hugo Hernández ${ }^{3}$, Lorena Hoyos ${ }^{1} \&$ Santander De la Ossa ${ }^{1}$ \\ ${ }^{1}$ Universidad de Sucre, Business Administration Program, Colombia \\ ${ }^{3}$ Universidad del Atlántico, Business Administration Program, Colombia \\ Correspondence: William Niebles Nuñez, Universidad de Sucre, Business Administration Program, Colombia, \\ email. E-mail: william.niebles@unisucre.edu.co
}

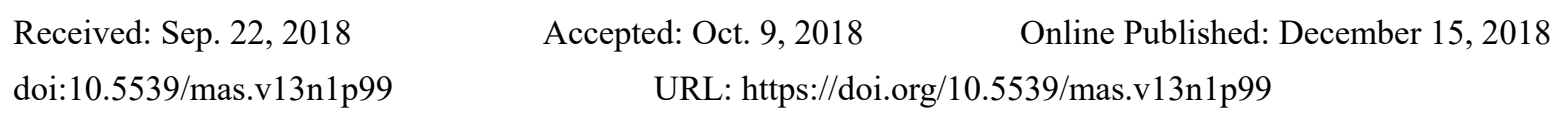

The research is financed by (Universidad de sucre - Atlantico).

\begin{abstract}
Small and medium enterprises (SMEs) are a driving factor in the Colombian economy, being fundamental for the generation of most of the country's employment; their limited conditions lead these organizations to face challenges to achieve a sustained position in the market and favorable returns. In this sense, strategic planning is presented as a response to the need to structure its actions according to the fulfillment of visions, missions and objectives coherent with the reality of its position in the market, and its internal conditions. This is how this research proposes an analysis of the main contributions of the use of methodologies, techniques and strategic management tools in SMEs, highlighting their contribution to the establishment of successful marketing plans, innovation and commitment of employees, as well as the integration of stakeholders. The methodology applied was of mixed cuts, since quantitative and qualitative paradigms were combined. The results allow to glimpse a great disposition on the part of the SMEs for the strategic management, nevertheless, there are few resources that are managed for such purpose.
\end{abstract}

Keywords: management, strategies, competitiveness, globalization, SMEs, markets

\section{Introduction}

SMEs in Colombia comprise approximately $96 \%$ of the business structure, and contribute nearly $75 \%$ of the country's employment (Mora, Vera and Melgarejo, 2015); their classification is defined by Law 590 of 2000, which, for classification, considers aspects such as the number of employees and the value of their assets, expressed in current legal monthly minimum wages (CLMMW), these criteria are shown in table 1.

Table 1. Criterias for the typification of SMEs de pymes

\begin{tabular}{lllll}
\hline \multirow{2}{*}{ Type } & \multicolumn{2}{c}{ Range of No. of workers } & \multicolumn{2}{c}{ Range of total assets } \\
\cline { 2 - 5 } & Min. & Max. & Min. & Max. \\
Medium & 51 & 200 & 100.000 SMMLV & 610.000 SMMLV \\
Small & 11 & 50 & 501 SMMLV & 100.000 UVT \\
Micro & 1 & 10 & 0 & 500 SMMLV \\
\hline
\end{tabular}

Source: Law 590 of 2000

SMEs is playing an increasingly important role in the economic growth of most countries (Palma, Sierra \& Arbeláez, 2016), being fundamental in generating employment and maximizing efficiency in the processes of distribution of human and material resources (Muñoz, 2012). This type of organization is characterized by being dynamic, innovative and efficient, in addition to its small size allows flexibility, immediate feedback, a shorter path to decision making, better understanding and faster response to customer needs (Idar, Yusoff and Mahmood 
2012).

Despite their advantages, SMEs are faced with challenging markets with companies with greater innovative, productive and logistical capacity, which forces them to define mechanisms to detect and take advantage of opportunities with greater speed and positive results (Verbano and Venturini, 2013).

\section{Method}

The proposed research method was framed within a mixed approach, i.e. a quantitative and qualitative approach to the analysis of information. In this way, both orientations were combined in a flexible way with the objective of achieving more complete results (Gómez, 2015). The type of research chosen was descriptive with propositive profile, non-experimental design, documentary and field. The instrument was designed based on a Likert scale and taking into consideration the study variables according to the established operationalization.

This type of scale allows to know the degree of agreement or not regarding a given approach and with it to know in a quantitative order the opinion of the respondents (Echauri, Minami and Sandoval, 2014). The universe taken was the SMEs registered at the Chamber of Commerce of the city of Barranquilla, with more than five years of operation. The sampling was intentional, taking from the universe 35 entities that were consulted protecting their data under the Habeas Data Law currently in force.

\section{Situation of SMEs}

Latin American SMEs are characterized by facing the same challenges and constraints, which is why Saavedra (2012) was able to bring together the most relevant aspects to be considered when determining the desired degree of competitiveness, and a consequent strategic management, such are:

- Public policy, macroeconomic management and functioning of state, and policy and promotion actions.

- Social issues.

- Financial management.

- Foreign trade.

- Internal market.

- Technlogy and innovation.

- Tax and labour aspects.

- Infrastructure.

- Enviroment.

According to the identified aspects it is possible to establish the importance of the use of strategic planning in determining the course of action of SMEs (Palma, 2011), the contributions are multiple and these range from an optimization of resources, better governance, to the strengthening of leadership and commitment of people linked to the organization (Hernández, Cardona \& Del Rio, 2017).

Strategic planning is a management method that employs various techniques and factors to perform specific tasks in a systematic manner, based on the achievement of clearly defined objectives and processes (Mazzarol and Reboud, 2014).

This methodology is characterized by long-term orientation, written strategies, and evaluation and monitoring (Johnston and Douglas, 2013). This orientation involves an extensive analysis of the environments in such a way as to help leaders and managers successfully address the major challenges facing their organization, especially in terms of (Bryson, 2018):

- Collecting, analysing and synthesising information in order to consider its strategic significance and frame possible choices.

- Production of judgments used to make decisions regarding missions, objectives, strategies and activities that are desirable, feasible, defensible and acceptable.

- Production of complementary judgements for decision making on new, modified or completed policies, programmes and projects, or general organizational designs.

- Promotion of continuous organisational learning.

- Creation of significant and lasting value.

A variety of tools and techniques are used to assist in the planning process so that input data can be transformed 
into appropriate forms of decision making (Kalkan and Bozkurt, 2013). Some of the benefits that have been recognized include increased awareness of the business environment, identification of strategic issues, as well as business opportunities and threats, an effective communication tool, among others (Elbanna, Andrews and Pollanen, 2016).

For their part, Dubihlela and Sandada (2014), in studying the application of strategic planning in SMEs, found that it increases employee participation, encourages implementation, and promotes evaluation and control in such a way that it is significant for business performance. On the other hand, several researchers have succeeded in demonstrating that participatory strategic planning positively impacts the implementation phase, increasing employee commitment to the achievement of objectives (Kohtamäki, Kraus, Mäkelä and Rönkkö, 2012).

Also, Hagen, Zucchella, Cerchiello and De Giovanni (2012), analyzed the SMEs according to their associativity and internationalization capacity, cataloguing them in four types, as they are a business group oriented to growth, to the client, to the product, and those that lack strategic orientation; from their study they were able to determine that the use of a clear and proactive strategic orientation, in accordance with the commercial strategy, contribute to a better performance in the international markets (Marín, Inciarte, Hernández \& Pitre, 2017).

The initial step in strategic planning is the correct formulation of the vision statement, considering its accuracy, timing and consistency, in order to establish a planning directed towards a desired horizon. From the vision formulated, the relevant strategic objectives are derived, thus constituting the basis for planning, which draws a scenario describing the type of change desired for the organization, considering that such design is considered true, although it is known that there may be changes originated by the conformation of risk.

In this sense, the construction of strategic scenario processes can be divided into six basic steps (Zahradníčková and Vacík, 2014):

- Identification of risk factors and evaluation of their significance.

- Choice of the key risk, which has an essential influence on the fulfilment of the strategic objectives.

- Formulation of scenarios and proof of their consistency.

- Establishing the probability that they may occur.

- Conduct gap analysis to establish the rate of compliance with the strategic objectives estimate.

- Correction of scenarios in the risk rate reserve for strategic planning.

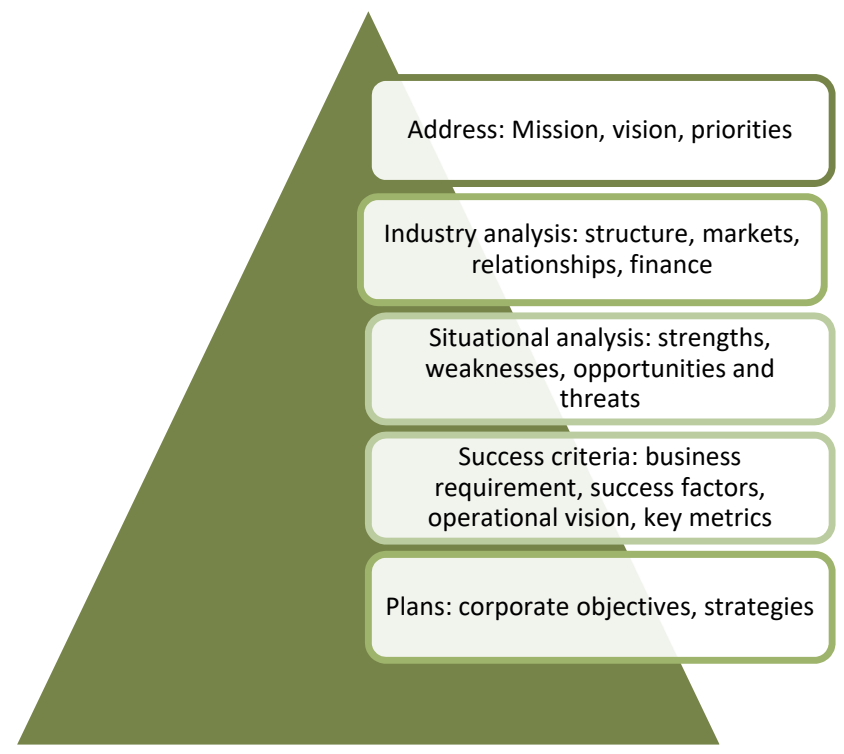

Figure 1. Components of a business plan, adapted from Cassidy (2016)

The use of these tools is determined by the level of depth of the analysis and the degree of investment required; tools such as the DOFA provide a view of the interior of the organization; on the other hand, benchmarking and analysis of market competitors provide studies of the external environment; in addition, there are tools such as brand analysis, financial, feasibility studies and others, which establish the probability of successfully carrying out projects. 


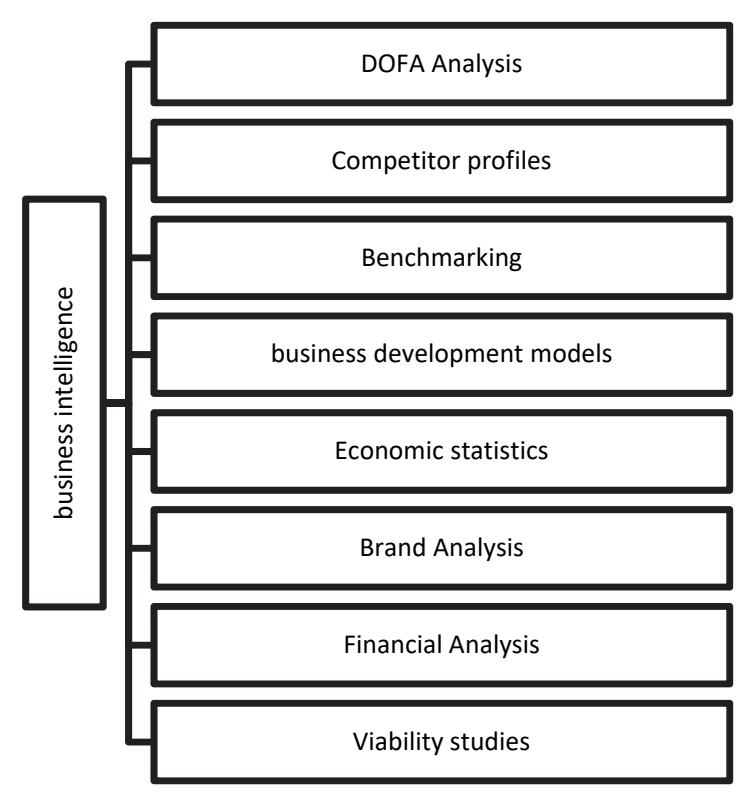

Figure 2. Tools for business intelligence

\section{Results}

In order to analyze the collected results, a matrix was designed with the purpose of identifying which are the components that are mostly being applied today in the 35 SMEs consulted. The following elements were considered for the study:

- DOFA analysis.

- Competitors Analysis.

- Development of Benchmarking.

- Business Model.

- Econometric statics.

- Analysis of brand.

- Financial analysis.

- Viability studies.

By tabulating and consolidating the information, the most noteworthy findings are summarized in table 2 . For reflection, an analysis of components is applied, observing the weight of each sub-variable in the main Strategic Management variable. See below with the reflections derived from the process. By tabulating and consolidating the information, the most noteworthy findings are summarized in table 1. For reflection, an analysis of components is applied, observing the weight of each sub-variable in the main Strategic Management variable. See below with the reflections derived from the process.

Table 2. Correlation coefficients of strategic management

\begin{tabular}{lll}
\hline Component & Correlation coefficient \\
\hline 1 & DOFA Analysis & 0,786 \\
2 & Competitors Analysis & 0,778 \\
3 & Development of Benchmarking & 0,717 \\
4 & Business models & 0,700 \\
5 & Econometrics Statistics & 0,671 \\
6 & Brand analysis & 0,634 \\
\hline
\end{tabular}




\begin{tabular}{lll}
\hline Component & Correlation coefficient \\
\hline 7 & Financial analysis & 0,50 \\
8 & Viability studies & 0,37 \\
\hline
\end{tabular}

When addressing the issue with the SMEs that participated in the study, it is specified that there is a program or line of strategic management in the organization. The most representative component according to the table is the Analysis using the DOFA tool, followed by Competitor Analysis, Business Models and Econometric Statistics. All the elements mentioned have significant values and are considered to be tools of great value for organizations today. on the other hand, the aspects of lesser impact, management or current applicability are located in the Feasibility Studies, Financial Analysis and Brand Analysis. The above is associated to a great extent to the aspects related to the budget, because while the first or better positioned do not always require a high budget, those of lesser impact if they demand greater investments for the development of the same.

\section{Conclusion}

The complexity of the world economy, and the influence it has on the development of trade, shortening times and reducing management spaces, forces SMEs to abandon their challenges and establish new mechanisms that allow them to be more competitive, using decision making with the speed required by the market. In this sense the new models of organization and the evolution on strategies of commercialization and patterns of production, are necessary to obtain strategic advantages that provide favorable positions in the market (Tabares, 2012).

In developing economies, SMEs are considered a source of innovation, flexibility and economic growth; however, the insufficiency of resources and the strong competition in the markets in which they operate generate strong volatility, as shown by the results presented, which suggest that it is important to believe in aspects such as: financial analysis and feasibility (Cleri, 2013). Thus, the strategic planning process is considered vital for this type of organizations, since it helps them adapt to a changing environment and can be applied to all levels of management (Gică and Balint, 2012); for this it is considered essential to cover the essential steps to successfully carry out a planning process, knowing that this is measured by the positive results it generates; in addition, the use of tools establishes an aid to be able to carry out analyses required with the necessary depth to obtain quality information and use it properly in decision making.

\section{Acknowledgements}

To the University of Sucre and the University of the Atlantic, our gratitude for the support and promotion of scientific research processes and for the support to the matrix project of this document "Approach to small and medium enterprises in the Caribbean region: a view from competitiveness".

\section{Competing Interests Statement}

The authors declare that there are no competing or potential conflicts of interest.

\section{References}

Bryson, J. M. (2018). Strategic Planning for Public and Nonprofit Organizations: A Guide to Strengthening and Sustaining Organizational Achievement. John Wiley \& Sons.

Cassidy, A. (2016). A practical guide to information systems strategic planning. New York: Auerbach Publications.

Cleri, C. (2013). El libro de las pymes. Ediciones Granica.

Dubihlela, J., \& Sandada, M. (2014). Impact of strategic planning on small and medium-sized enterprises'(SMEs) performance: The role of employee participation, implementation incentives and evaluation and control. Journal of Economics, 5(1), 45-55. https://doi.org/10.1080/09765239.2014.11884983

Echauri, A. M. F., Minami, H. y Sandoval, M. J. I. (2014). La Escala de Likert en la evaluación docente: acercamiento a sus características y principios metodológicos. Perspectivas docentes, (50).

Elbanna, S., Andrews, R., \& Pollanen, R. (2016). Strategic planning and implementation success in public service organizations: Evidence from Canada. Public Management Review, 18(7), 1017-1042. https://doi.org/10.1080/14719037.2015.1051576

Gică, O. A., \& Balint, C. I. (2012). Planning practices of SMEs in North-Western region of Romania-An empirical investigation. Procedia Economics and Finance, 3, 896-901. https://doi.org/10.1016/s2212-5671(12)00247$\mathrm{x}$ 
Gómez, M. C. S. (2015). La dicotomía cualitativo-cuantitativo: posibilidades de integración y diseños mixtos. Campo Abierto. Revista de Educación, 11-30.

Hagen, B., Zucchella, A., Cerchiello, P., \& De Giovanni, N. (2012). International strategy and performanceClustering strategic types of SMEs. International Business Review, 21(3), 369-382. https://doi.org/10.1016/j.ibusrev.2011.04.002

Hernández, H. G., Cardona, D. A. \& Del Rio, J. L. (2017). Direccionamiento Estratégico: Proyección de la Innovación Tecnológica y Gestión Administrativa en las Pequeñas Empresas. Información tecnológica, 28(5), 15-22. https://doi.org/10.4067/s0718-07642017000500003

Idar, R., Yusoff, Y., \& Mahmood, R. (2012). The effect of market orientation as mediator to strategic planning practices and performance relationship: Evidence from Malaysian SMEs. Procedia Economics and Finance, 4, 68-75. https://doi.org/10.1016/s2212-5671(12)00322-x

Johnston, R. E., \& Douglas, B. J. (2013). The Power of Strategy Innovation: A New Way of Linking Creativity and Strategic Planning to Discover Great Business Opportunities. AMACOM.

Kalkan, A., \& Bozkurt, Ö. Ç. (2013). The choice and use of strategic planning tools and techniques in Turkish SMEs according to attitudes of executives. Procedia-Social and Behavioral Sciences, 99, 1016-1025. https://doi.org/10.1016/j.sbspro.2013.10.575

Kohtamäki, M., Kraus, S., Mäkelä, M., \& Rönkkö, M. (2012). The role of personnel commitment to strategy implementation and organisational learning within the relationship between strategic planning and company performance. International Journal of Entrepreneurial Behavior \& Research, 18(2), 159-178. https://doi.org/10.1108/13552551211204201

Ley 590 de 2000. Por la cual se dictan disposiciones para promover el desarrollo de las micro, pequeñas y medianas empresa. Bogotá D.C.

Marín, F. V., Inciarte, A. D. J., Hernández, H. G., \& Pitre, R. C. (2017). Estrategias de las Instituciones de Educación Superior para la Integración de las Tecnología de la Información y la Comunicación y de la Innovación en los Procesos de Enseñanza. Un Estudio en el Distrito de Barranquilla, Colombia. Formación universitaria, 10(6), 29-38. https://doi.org/10.4067/s0718-50062017000600004

Marulanda, C., López, M., \& López, F. (2016). La cultura organizacional y las competencias para la gestión del conocimiento en las pequeñas y medianas empresas (pymes) de Colombia. Información tecnológica, 27(6), 03-10. https://doi.org/10.4067/s0718-07642016000600002

Mazzarol, T., Clark, D. N., \& Reboud, S. (2014). Strategy in action: Case studies of strategy, planning and innovation in Australian SMEs. Small Enterprise Research, 21(1), 54-71. https://doi.org/10.1080/13215906.2014.11082076

Mora-Riapira, E. H., Vera-Colina, M. A., \& Melgarejo-Molina, Z. (2015). Planificación estratégica y niveles de competitividad de las Mipymes del sector comercio en Bogotá. Estudios Gerenciales, 31(134), 79-87. https://doi.org/10.1016/j.estger.2014.08.001

Muñoz H., M. H. (2012). Comunicación y productividad en pequeñas y medianas empresas de un cluster textil en Colombia. Contaduría y administración, 57(2), 223-244.

Palma, H. G. H. (2011). La gestión empresarial, un enfoque del siglo XX, desde las teorías administrativas científica, funcional, burocrática y de relaciónes humanas. Escenarios, 9(1), 38-51. https://doi.org/10.18041/2382-3240/saber.2016v11n1.499

Palma, H. H., Sierra, D. M., \& Arbeláez, D. C. (2016). Enfoque basado en procesos como estrategia de dirección para las empresas de transformación. Saber, Ciencia y Libertad, 11(1), 141-150. https://doi.org/10.18041/2382-3240/saber.2016v11n1.499

Saavedra G., M. L. (2012). Una propuesta para la determinación de la competitividad en la pyme latinoamericana. Pensamiento \& Gestión, 33, 93-124.

Tabares A. S. (2012). Revisión analítica de los procesos de Internacionalización de las PYMES. Pensamiento \& Gestión, 33, 67-92.

Verbano, C., \& Venturini, K. (2013). Managing risks in SMEs: A literature review and research agenda. Journal of Technology Management \& Innovation, 8(3), 186-197. https://doi.org/10.4067/s071827242013000400017 
Zahradníčková, L., \& Vacík, E. (2014). Scenarios as a strong support for strategic planning. Procedia Engineering, 69, 665-669. https://doi.org/10.1016/j.proeng.2014.03.040

\section{Copyrights}

Copyright for this article is retained by the author(s), with first publication rights granted to the journal.

This is an open-access article distributed under the terms and conditions of the Creative Commons Attribution license (http://creativecommons.org/licenses/by/4.0/). 